\title{
THE JAPANESE LABRID FISH CORIS MUSUME, A JUNIOR SYNONYM OF THE AUSTRALIAN C. PICTA
}

$\operatorname{AUTHOR}(S)$ :

Randall, John E.; Araga, Chuichi

\section{CITATION:}

Randall, John E....[et al]. THE JAPANESE LABRID FISH CORIS MUSUME, A JUNIOR SYNONYM OF THE AUSTRALIAN C. PICTA. PUBLICATIONS OF THE SETO MARINE BIOLOGICAL LABORATORY 1978, 24(4-6): 427-431

ISSUE DATE:

1978-10-15

URL:

http://hdl.handle.net/2433/175971

RIGHT: 


\title{
THE JAPANESE LABRID FISH CORIS MUSUME, A JUNIOR SYNONYM OF THE AUSTRALIAN $C$. PICTA $A^{12)}$
}

\author{
JOHN E. RANDALL \\ Bernice P. Bishop Museum, Box 6037, Honolulu, Hawaii 96818, USA \\ and \\ Chuichi ARAGA \\ Seto Marine Biological Laboratory \\ With Text-figures $1-2$
}

Coris picta was described (as Labrus pictus) by Bloch and Schneider (1801: 251, pl. 55) from New Holland (interpreted as New South Wales by McCulloch, 1929). Ramsay (1883: 301) named it a second time, as Coris semicincta, from a specimen taken near Broken Bay, New South Wales and another from Lord Howe Island. Under the common name heading of "combfish," Marshall (1964: 308, pl. 45) gave the distribution as Moreton Bay, South Queensland $\left(27^{\circ} \mathrm{S}\right)$, New South Wales, and Lord Howe Island, and recorded the length to 11 inches.

Doak (1972: 88-91, pl. 37) reported Coris picta from Poor Knights Islands, NE North Island, New Zealand. He described the typical habitat as rocky areas close to sand, the sand being necessary since Coris buries in it at nightfall to sleep. $\mathrm{He}$ noted that the species maintains a home range. In 1972 he observed large individuals, to $22 \mathrm{~cm}$ in total length. These had a more prominent comb pattern along the lower edge of the dark lateral band. He could detect no male-female differences until on one occasion he saw a large individual with a peculiar color pattern. The dorsum was blue-gray instead of white, the pectoral fins was yellow with dark blue tips, the anal fin was yellow, and the belly gray-yellow. This fish was making lateral displays to a normal-colored individual slightly smaller than itself, which began to respond. He realized from the later spawning act that the larger fish was a male and the smaller a female. The male positioned himself above and slightly behind the female with his pelvic fins on each side of her dorsal fin. The two fish rose together; at the peak of their asecnt the female turned slightly on her side and held this position for about four seconds while spawning occurred. The spawning run was repeated four times. Later the male was observed to revert to the normal coloration.

1) Contributions from the Seto Marine Biological Laboratory, No. 649.

2) Supported in part by National Science Foundation Grant No. DEB 76-21874.

Publ. Seto Mar. Biol. Lab., XXIV (4/6), 427-431, 1978.

(Article 27) 
Ayling and Grace (1971) and Doak (op. cit.) described the cleaning behavior of Coris picta. This species is a facultative cleaner; much of its food is benthic. The large adults rarely clean other fishes.

Grace (1973) recorded the species at the Aldermen Islands, off North Island, New Zealand $\left(37^{\circ} \mathrm{S}\right)$. He and Doak (op. cit.) believe the species naturally became established at Poor Knights Islands as it had not been seen before 1969, and the first individual sighted was a juvenile. A breeding population developed at the islands between 1969 and 1973. Grace (op. cit.) and Ayling and Russell (1976) corrected the earliest New Zealand records of C. picta by Russell (1969) and Stephenson (1970) as misidentifications of Coris sandageri.

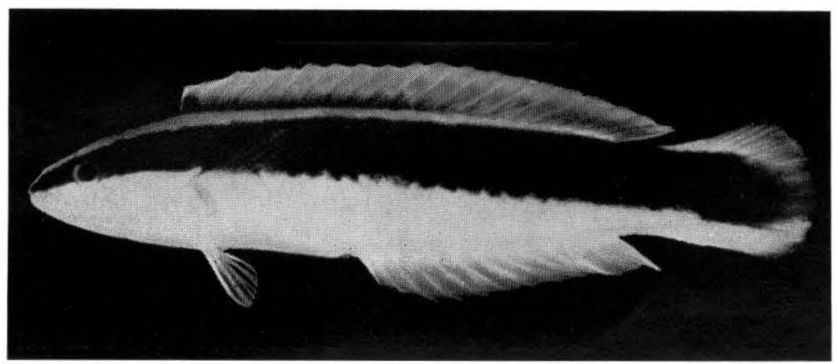

Fig. 1. Coris picta, juvenile, 59 mm SL, Lord Howe Island, BPBM 14751.



Fig. 2. Coris picta, female, 167 mm SL, Lord Howe Island, BPBM 14774.

The senior author and associates collected C. picta at Lord Howe Island in 1973 (Allen et al., 1976: 418). One juvenile of $59 \mathrm{~mm} \mathrm{SL} \mathrm{(Fig.} \mathrm{1)} \mathrm{was} \mathrm{taken} \mathrm{in} \mathrm{the} \mathrm{lagoon}$ in only $1.5 \mathrm{~m}$. Two adults, a $167-\mathrm{mm}$ female (Fig. 2), a $212-\mathrm{mm}$ male, and three juveniles $45-86 \mathrm{~mm}$ SL were collected in 16 to $25 \mathrm{~m}$ at North Rock. These specimens have been deposited at the Bishop Museum, along with one other of $67 \mathrm{~mm}$ SL collected at Jervis Bay, New South Wales $\left(35^{\circ} \mathrm{S}\right)$ by B. Russell, a gift from the Australian Museum. 
Coris musume was described (as Julis musume) by Jordan and Snyder (1904: 236, pl. 61) from off Izu, Japan. Jordan, Tanaka, and Snyder (1913) gave the distribution as Tokyo to Nagasaki. Yu (1968: 84, fig. 36) (after Liang) extended the range to Keelung (=Chilung), Taiwan $\left(25^{\circ} \mathrm{N}\right)$.

Kamohara (1950: 172) (1958: 13) was the first to regard musume as a synonym of $C$. picta. He gave the range in Japan as Chiba Prefecture (Kominato) to Kochi Prefecture, adding that the species is very rare. He has not been followed by later authors, however, such as Tomiyama and Abe (1958), Abe (1963), Matsubara (1964), Yu (1968), and Masuda, Araga and Yoshino (1975) who continue to use C. musume.

We have made a direct comparison of Australian specimens of $C$. picta and Japanese specimens of $C$. musume and can find no significant differences between the two. We therefore follow Kamohara in regarding C. musume (Jordan and Snyder) as a junior synonym of $C$. picta.

The following diagnosis of $C$. picta was prepared from our combined material.

Diagnosis: Dorsal rays IX, 12; anal rays III, 12; pectoral rays 14; lateral-line scales 76 to 92 (plus two beyond caudal base); gill rakers 6 or $7+12$ or 13 (usually $7+12)$.

Depth of body 3.7 to 4.5 in SL (depth usually proportionally less in larger individuals); head length 3.0 to 3.6 in SL (head usually proportionally shorter in larger individuals); diameter of orbit varying from 4.2 in head (of $45-\mathrm{mm}$ juvenile) to 6.6 (212-mm male); first two dorsal spines not elongate and flexible in adults, and the bases not closer together than remaining spines; dorsal spines progressively longer, the first about three-fourths the length of second, the last 3.0 to 3.3 in head; caudal fin rounded, 1.3 to 1.6 in head (fin relatively longer in smaller individuals); pectoral fins 1.45 to 1.7 in head; pelvic fins short, 1.5 to 2.2 in head (fins longest in $212-\mathrm{mm}$ male, just reaching anus). Anterior canine teeth more than twice as large as second teeth in jwas.

Color in alcohol light brown with a dark brown to black stripe from front of snout through eye and broadening as it passes posteriorly along upper side of body to caudal fin (in juveniles the band is broader, continuous, and it reaches posterior edge of caudal fin; in adults the band has numerous ventral projections from the lower edge, it is interrupted posteriorly on the head by a portion which curves to the lower edge of the opercular membrane, and it ends on approximately the basal fourth of caudal fin; also in adults there is a pale zone adjacent and below the dark lateral stripe); a median dark streak on interorbital space, extending a variable distance posteriorly, but usually not reaching origin of dorsal fin; a black spot anteriorly on dorsal fin and a dusky band basally in fin (broader and anteriorly); large adults with blackish on tip of pectoral fins (notably broader on males than females); remaining fins pale.

In life a median dorsal red band on head, best developed on nape, which may continue along base of anterior part of dorsal fin; posterior part of dark basal band 
in dorsal fin reddish; pale zone above black lateral stripe varies from light yellowish to light pinkish; body below lateral stripe white; caudal fin posterior to end of black lateral band bright yellow (adults therefore have more yellow on caudal fin than smaller fish, and small juveniles none); base of pectoral fins yellow.

Remarks: H.-J. Paepke searched for the holotype of Labrus pictus Bloch and Schneider at the Zoologisches Museum of Humboldt University in East Berlin for us, but he was unable to find it.

The description of Coris musume by Jordan and Snyder (1904) was based on two "cotypes," one of which was deposited at Stanford University and is now at the California Academy of Sciences (SU 8384, $172 \mathrm{~mm} \mathrm{SL}$ ). The other was said to be at the United States National Museum, but it cannot be located today and is presumed lost.

Coris picta ranges in the western Pacific from about 25 to $35^{\circ}$ in the northern hemisphere and 27 to $37^{\circ}$ in the southern. We know of no records from the intervening tropical area such as the East Indian region or Philippines. We therefore conclude that it has an anti-tropical distribution. Randall (MS) has summarized the examples of species of fishes of the Indo-West-Pacific such as C. picta which exhibit disjunct north-south distribution.

Our largest specimen (BPBM 14774) is a male from Lord Howe Island which measures $212 \mathrm{~mm}$ SL.

\section{Acknowledgements}

We thank the following persons for the loan of specimens or pertinent information: Jack T. Moyer of the Tanaka Memorial Biological Station H.-J. Paepke of the Zoologisches Museum of Humboldt University, John W. Shepard of the University of Guam, Pearl M. Sonoda of the California Academy of Sciences, Victor G. Springer of the U.S. National Museum of Natural History, Takeshi Tatsuki of the Sabiura Marine Park Research Station and Tetsuo Yoshino of the University of Ryukyus.

\section{REFERENCES}

Abe, T., 1963: Keys to the Japanese fishes fully illustrated in colors. Ed. 2, 5+358 pp., Hokuryukan, Tokyo. (in Japanese)

Ayling, A.M. and R.V. Grace, 1971: Cleaning symbiosis among New Zealand fishes. New Zealand Jour. Mar. Fershw. Res., 5(2), pp. 205-218.

Ayling, A.M. and B.C. Russell, 1976: New records of fihes from northeastern New Zealand, 6(3), pp. $277-286$.

Bloch, M.E. and J.G. Schneider, 1801: Systema ichthyologiae iconibux illustrautm, 1x+584 pp. Sanderiano, Berlin.

Doak, W., 1972: Fishes of the New Zealand region, 132 pp. Hodder and Stoughton, Auckland.

Grace, R.V., 1973: A checklist of fishes of the Aldermen Islands, northeastern New Zealand, with additions to the fihes of Red Mercury Island. Tane, 19, pp. 13-19.

Jordan, D.S. and J.O. Snyder, 1904: On a collection of fishes made by Mr. Alan Owston in the deep waters of Japan. Smithson. Misc. Coll., 1(3/4), pp. 230-240.

Jordan, D.S., S. Tanaka, and J.O. Snyder, 1913: A catalogue of the fishes of Japan. Jour. Coll. Sci. Tokyo Imp. Univ., 23(1), $497 \mathrm{pp}$. 
Kamohara, T, 1950: Description of the fishes from the Provinces of Tosa and Kishu, Japan, 3+ $288+5+48+27$ pp. (in Japanese)

- 1958: A review of the labrid fishes found in the waters of Kochi Prefecture, Japan. Rept. Usa Mar. Biol. Sta. 5(2), pp. 1-20.

Marshall, T.C., 1964: Fishes of the Great Barrier Reef. 566 pp., Angus and Robertson, Syndey. Masuda, H., C. Araga, and T. Yoshino, 1975: Coastal Fishes of Southern Japan. 379 pp., Tokai University Press, Tokyo.

Matsubara, K., 1964: Fish morphology and hierarchy, pt. 2, v+pp. 791-1605, Ishizaki-Shoten, (in Japanese)

McCulloch, A.R., 1929: A check-list of the fishes recorded from Australia. Mem. Austral. Mus. 5, part 3, pp. $329-436$.

Ramsay, E.P., 1883: Description of a new species of Coris from Lord Howes Island and New South Wales. Proc. Linn. Soc. New South Wales, 12(2), pp. 301-302.

Russell, B.C., 1969: A checklist of fishes of Goat Island, North Auckland, New Zealand, with an analysis of habitats and associations. Tane 15, pp. 105-113.

Stephenson, A.B., 1970: Some new records of fish in New Zealand waters. Rec. Auckland Inst. Mus. 7, pp. 197-200.

Tomiyama, I. and T. Abe, 1958: Encyclopaedia zoologica illustrated in colours, vol. 2, 392 pp., Hokuryukan, Tokyo. (in Japanese)

Yu, M-J, 1968: The labrid fishes of Taiwan. (Ichth. ser. 4), Biol. Bull. Coll. Sci. Tunghai Univ. 30, pp. $1-136$. 